\title{
Importance of the ammonia assimilation by Penicillium purpurogenum in amino derivative Monascus pigment, $\mathrm{PP}-\mathrm{V}$, production
}

\author{
Teppei Arai, Kasumi Koganei, Sara Umemura, Ryo Kojima, Jun Kato, Takafumi Kasumi and Jun Ogihara*
}

\begin{abstract}
A fungal strain, Penicillium purpurogenum IAM 15392, produced the azaphilone Monascus pigment homolog when cultured in a medium composed of soluble starch, ammonium nitrate, yeast extract, and citrate buffer, $\mathrm{pH}$ 5.0. One of the typical features of violet pigment PP-V [(10Z)-12-carboxyl-monascorubramine] is that pyranoid oxygen is replaced with nitrogen. In this study, we found that glutamine synthetase $(\mathrm{g} \ln B)$ and glutamate dehydrogenase (gdh1) genes were expressed in the culture conditions conducive to PP-V production. Gln and Glu both support PP-V biosynthesis, but PP-V biosynthesis was much more efficient with $\mathrm{Gln}$. We determined that synthesis of Gln by glutamine synthetase from ammonium is important for PP-V production.
\end{abstract}

Keywords: Monascus pigment, Amino derivative, Penicillium purpurogenum, Ammonia assimilation, Glutamine synthetase, Glutamate dehydrogenase

\section{Introduction}

Since ancient times, Monascus spp. have been used as starter cultures in the brewing of red rice wine, and Monascus pigments have been used as a natural food colorant in East Asia (Juzlova et al. 1996; Dufosse 2006). Monascus pigments comprise six major compounds, including the yellows of monascin (Birch et al. 1962; Chen et al. 1971; Fielding et al. 1961) and ankaflavin (Manchand et al. 1973), oranges of monascorubrin (Hadfield et al. 1967: Kurono et al. 1963) and rubropunctatin (Haws and Holker 1961), and reds of monascorubramine (Hiroi et al. 1975) and rubropunctamine (Fowell et al. 1956). Pigments produced by Monascus spp. were recently demonstrated to have physiological activities as antibacterial, anticancer, and antioxidant agents (Kim et al. 2006; Akihisa et al. 2005; Akihisa et al. 2005). However, except for a few strains that have been developed for commercial use, Monascus spp. have also been found to produce citrinin, which is a mycotoxin (Blane et al. 1995; Wang et al. 2005). For this reason, Monascus pigments are not approved as food ingredients in the European Union or the United States.

\footnotetext{
* Correspondence: j-ogihara@brs.nihon-u.ac.jp Department of Chemistry and Life science, College of Bioresource Sciences, Graduate School of Bioresource Sciences, Nihon University, 1866 Kameino, Fujisawa, Kanagawa 252-0880, Japan
}

Penicillium purpurogenum IAM 15392 has been found to produce Monascus pigment homologs in culture with a specific medium (Ogihara et al. 2000; Ogihara et al. 2001; Ogihara and Oishi 2002). This strain does not produce citrinin, making $P$. purpurogenum IAM15392 a potentially valuable commercial source of natural food colorant.

Many of the filamentous fungus Penicillium spp. are known to produce red pigments that contain quinone and phenolic compounds (Takeda et al. 1973; Gatenbeck 1959; Bu'Lock and Smith 1968; Cason et al. 1962; Simonart and Verachtert 1966; Fuska et al. 1988; Peterson and Grove 1983; Singh et al. 1985; Kobayashi et al. 1987). P. purpurogenum IAM 15392 has been found to produce Monascus pigment homologs PP-V [(10Z)-12-carboxylmonascorubramine] and PP-R [(10Z)-7-(2-hydroxyethyl)monascorubramine] in culture with a medium composed of ammonium nitrate, soluble starch, yeast extract, and citrate buffer at $\mathrm{pH}$ 5.0. In an ammonium nitrate-free medium, PP-O [(10Z)-12-carboxyl-monascorubrin] and PP-Y [(10Z)-monascorubrin] pigment were produced instead of PP-V and PP-R, respectively (Ogihara et al. 2000; Ogihara et al. 2001; Ogihara and Oishi 2002). PP-V is a nitrogen-containing polyketide compound that is important as a secondary metabolite for microorganisms. The 
nitrogen atom in the nitro compound often exhibits various biological activities with medical and agrochemical applications. As a nitrogen source for PP-V production, culture of $P$. purpurogenum IAM15392 with ammonium nitrate results in an efficient and stable yield of the pigment. Based on the structural characteristics of 7-NH in $\mathrm{PP}-\mathrm{V}$, the role of ammonia nitrogen in pigment production was suggested.

Monascus spp. are reported to produce various derivatives of Monascus pigments with the supplementation of specific amino acids in culture broth. Glutamic acid, aspartic acid and alanine derivatives of Monascus pigment have been identified and characterized (Lin et al. 1992; Blanc et al. 1994; Hajjaj et al. 1997; Sato et al. 1997). Further, Jung et al. obtained various pigment derivatives using 20 amino acids as side chain precursors (Jung et al. 2003). The features of pigment production by $P$. purpurogenum IAM15392 include the production of PP-V, an amino derivative of the PP-O Monascus pigment homolog, when cultured in a medium supplemented with ammonium nitrate (Ogihara et al. 2000). However, little is known about the profile and characteristics of Monascus pigment derivatives produced in growth medium supplemented with inorganic nitrogen (Chen and Johns 1993).

The addition of ammonium ion with ammonium nitrate is important in PP-V production in culture broth, and $\mathrm{NO}_{3}{ }^{-}$is used for PP-V production after reduction to $\mathrm{NH}_{4}{ }^{+}$through an in situ bioprocess (Arai et al. 2012). We are therefore interested in the effect of the type of nitrogen source on incorporation into PP-V. Nitrogen, one of the most important biogenic elements, is incorporated into the cell in an inorganic (nitrate, nitrite, ammonia) or an organic (amino acids, urea, other nitrogen compounds) form. Ammonia is transported into the cell or forms a metabolite of nitrate or nitrite and is converted to amino acids by ammonia assimilation involving two principal enzymes: glutamate dehydrogenase (Gdh; EC 1.4.1.2 and EC 1.4.1.4) and glutamine synthetase (GS; EC 6.3.1.2). Fungal ammonium assimilation is reported to occur via incorporation into Glu and Gln by glutamate dehydrogenase A (GdhA) and GS (Hammond and Wood 1985; Casper et al. 1985; Dunn-Coleman et al. 1981; Limon-Lason et al. 1977).

In this study, we investigated the effect of nitrogen source on its incorporation into PP-V production. Expression of GS and Gdh genes, and inhibition of pigment production using a specific inhibitor of GS, L-methionine -DL-sulfoximine (MSX), were analyzed. We discuss how GS and Gdh contribute to ammonium assimilation and PP-V production.

\section{Materials and methods}

Fungal material

P. purpurogenum IAM 15392 was used in this study. A culture of $P$. purpurogenum IAM 15392 was deposited in the IAM Culture Collection, Institute of Molecular and Cellular Biosciences, The University of Tokyo and as JCM 23216 in the Japan Collection of Microorganisms, RIKEN Bioresource Center, Japan.

\section{Pigment production medium}

One loopful of spores and mycelia of strain IAM15392 from a stock culture grown on YMA plates (10 g of glucose, $5 \mathrm{~g}$ of peptone, $3 \mathrm{~g}$ of yeast extract, $3 \mathrm{~g}$ of malt extract, and $20 \mathrm{~g}$ of agar per liter) was inoculated into a 500-ml Erlenmeyer flask containing $100 \mathrm{ml}$ of a PP-V production medium (20 g of soluble starch, $2 \mathrm{~g}$ of yeast extract and $3 \mathrm{~g}$ of ammonium nitrate per liter of $50 \mathrm{mM}$ citric acid/ $\mathrm{Na}_{3}$ citrate buffer, $\mathrm{pH}$ 5.0) and $\mathrm{PP}-\mathrm{O}$ production medium (20 $\mathrm{g}$ of soluble starch and $2 \mathrm{~g}$ of yeast extract per liter of $50 \mathrm{mM}$ citric acid/ $\mathrm{Na}_{3}$ citrate buffer, $\mathrm{pH}$ 5.0) and cultivated at $30^{\circ} \mathrm{C}$ with shaking at $200 \mathrm{rpm}$ for $72 \mathrm{hr}$.

\section{Sequencing and bioinformatic analysis}

Genomic DNA was extracted from mycelium grown in stationary liquid culture and used in sequencing. Shotgun sequencing was performed at the Hokkaido System Science with the GS FLX Titanium system (Roche Diagnostics, Mannheim, Germany). The 454 sequencing reads were assembled into contigs with the GS De Novo Assembler software (Roche Diagnostics). The contigs were converted to Blast database format for local blast searches using stand-alone Blast software (ver. 2.2.22) downloaded from the NCBI website. Gene predictions were manually checked by comparing the sequences with homologous gene/proteins in the GenBank database. Functional domains in the translated protein sequences were predicted using Conserved Domain Search (NCBI).

\section{Characterization of GS and Gdh genes}

To characterize GS and $G d h$ genes present in $P$. purpurogenum IAM15392, genomic sequences obtained by sequencing were used to search for homologous GS and $G d h$ gene sequences through a blastX search of NCBI. Primers for the amplification of $G S$ and $G d h$ genes were designed based on the obtained consensus sequences (Table 1).

\section{RNA extraction and reverse transcription}

P. purpurogenum IAM15392 cells cultured for $48 \mathrm{~h}$ in basal medium and basal medium containing $\mathrm{NaNO}_{3}$ were subjected to RNA extraction with FAvorPrepTM Plant Total RNA Mini kit (Favorgen Biotech, Ping-Tung, Taiwan). Total RNA $(1.5 \mu \mathrm{g})$ was reverse transcribed with PrimeScript ${ }^{\circledR}$ Reverse Transcriptase (Takara Bio, Shiga, Japan) using dT 15 primer. 
Table 1 Primers used for reverse transcription (RT)-PCR and real-time (qRT)-PCR

\begin{tabular}{|c|c|}
\hline Name & Primer sequence \\
\hline \multicolumn{2}{|c|}{ Reverse transcription PCR } \\
\hline glnA-for & 5'-GGCTTCTGCTCGGTGATCTT-3' \\
\hline glnA-rev & 5'-GACTGGGCCAGCTTATCCAC-3' \\
\hline glnB-for & 5'-GTCCTTGCGAGGGTATCGAG-3' \\
\hline glnB-rev & $5^{\prime}$-CGACCAGTCAGACGCTCATC-3' \\
\hline gdh1-for & 5'-TCCGACGATCTCAATGTTGG-3' \\
\hline gdh1-rev & $5^{\prime}$-CGCCGTCTACATCGATACCA-3' \\
\hline gdh2-for & 5'-AAAGTGAATATGGGTGGCGG-3 \\
\hline gdh2-rev & 5'-TCCAGTTGCTTCAGGTCGAA-3' \\
\hline \multicolumn{2}{|c|}{ Real-time PCR } \\
\hline glnB-RT-for & 5'-GAGGGTATCGAGATGGGTGA-3 \\
\hline glnB-RT-rev & 5'-GGTGGAAGGAGATCTGGACA-3 \\
\hline gdh1-RT-for & $5^{\prime}$-GTGTTACCTCGCTAGACGGC-3' \\
\hline gdh1-RT-rev & 5'-TCTACTCGATAGCTTCGCCC- $3^{\prime}$ \\
\hline
\end{tabular}

\section{Expression analysis of GS and Gdh genes}

Expression analysis of $G S$ and $G d h$ genes was examined by reverse transcription (RT)-PCR and real-time (qRT)PCR. RT-PCR was performed using first-strand cDNA as the template using the primers designed for amplification of GS and Gdh shown in Table 1. The amplification was carried out with an initial denaturation at $95^{\circ} \mathrm{C}$ for $5 \mathrm{~min}$, followed by 30 cycles of $95^{\circ} \mathrm{C}$ for $30 \mathrm{~s}, 55^{\circ} \mathrm{C}$ for $30 \mathrm{~s}$, and $72^{\circ} \mathrm{C}$ for $30 \mathrm{~s}$.

qRT-PCR was performed using LightCycler Fast Start DNA Master SYBR Green I with a LightCycler system (LightCycler 330, Roche Diagnostics). P. purpurogenum IAM15392 GAPDH was used as the reference gene for RT-PCR.

\section{Effect Gln and Glu on PP-V production}

P. purpurogenum IAM15392 in medium for PP-O production supplemented with 1 to $15 \mathrm{mM} \mathrm{L-Gln}$ and LGlu was cultured at $30^{\circ} \mathrm{C}$ with shaking at $200 \mathrm{rpm}$ for $120 \mathrm{hr}$. The culture broth was centrifuged $(3,000 \mathrm{rpm}$, $4^{\circ} \mathrm{C}, 10 \mathrm{~min}$ ) and pigments in the resulting supernatant were extracted with EtOAc and subjected to silica gel TLC analysis.

\section{Purification of pigments containing Gln}

For the purification of pigments, $P$. purpurogenum IAM15392 was cultured in PP-O production medium containing 1 to $15 \mathrm{mM} \mathrm{L}-\mathrm{Gln}$ at $30^{\circ} \mathrm{C}$ with shaking at $200 \mathrm{rpm}$ for $120 \mathrm{hr}$. After $120 \mathrm{hr}$, cultures were filtered through ADOVANTEC filter paper No. 2 (Toyo Roshi, Tokyo, Japan), and the pigment in the filtrate was extracted with EtOAc. The obtained extract was further purified by silica gel and Sephadex
LH-20 column chromatography, as described previously (Ogihara et al. 2000).

\section{Pigment analysis}

Pigments were detected by thin-layer chromatography using silica gel $60 \mathrm{~F}_{254}$ plates (Merck, Darmstadt, Germany) and developed in $n$-BuOH:AcOH: $\mathrm{H}_{2} \mathrm{O}$ (12:3:5) solvent. ${ }^{1} \mathrm{H}$ and ${ }^{13} \mathrm{C}$ NMR spectra were recorded using an ECA-500 spectrometer (JEOL, Tokyo, Japan).

\section{Effect of GS inhibition on pigment production}

Concentration-dependent effects of GS-specific inhibitor L-methionine-DL-sulfoximine (MSX) were evaluated. $P$. purpurogenum IAM15392 was cultured in PP-V production medium containing 0,1 , and $2 \mathrm{mM} \mathrm{MSX}$ at $30^{\circ} \mathrm{C}$ with shaking at $200 \mathrm{rpm}$ for $72 \mathrm{hr}$. The cultures were centrifuged $\left(3,000 \mathrm{rpm}, 4^{\circ} \mathrm{C}, 10 \mathrm{~min}\right)$ and pigments in the resulting supernatant were extracted with EtOAc and subjected to silica gel TLC analysis.

\section{Results}

\section{Exploration of GS and Gdh genes}

Two GS genes ( $g \ln A: \mathrm{AB7} 76940$ and $g \ln B: \mathrm{AB} 746941)$ and two Gdh genes (gdh1:AB746942 and $g d h 2: A B 746943)$ were identified from $P$. purpurogenum IAM15392 draft sequence data. These sequences showed high homology to the respective GS and Gdh genes of filamentous fungi (Table 2). The sequences has been submitted to GenBank database.

\section{Expression of GS and Gdh genes}

Expression of GS and Gdh genes showed that $g \ln B$ and $g d h 1$, respectively, were expressed in PP-V production condition (Figure 1). In contrast, $g \ln A$ and $g d h 2$ amplification products produced only faint bands on agarose gel, demonstrating that $g \ln A$ and $g d h 2$ are expressed at very low levels under the conditions of PP-V production.

Examination of $g \ln B$ and $g d h 1$ expression levels by qRT-PCR showed that $G \ln B$ expression was slightly higher than that of $g d h 1$, but the differences could not be clearly differentiated (Figure 2).

\section{Effect of Gln and Glu supplementation on PP-V production}

The effects of Gln and Glu supplementation on pigment production are shown in Figure 3. The violet pigment, Rf, was observed at Rf 0.75 (Ogihara et al. 2000). When cultured with Gln, the violet pigment, Gln-V, was observed at concentration of 10 and $15 \mathrm{mM}$ and increased with increasing Gln concentration. However, violet pigment was observed only for cultures supplied with $15 \mathrm{mM}$ Glu. Gln supplementation stimulated Gln-V production much more effectively than did Glu (Figure 3). 
Table 2 GS and Gdh gene in Penicillium purpurogenum IAM15392

\begin{tabular}{|c|c|c|c|}
\hline Gene & Protein homolog (accession number) & Source of protein homolog & Identities \\
\hline \multirow[t]{3}{*}{$g \ln A$} & glutamine synthetase, putative (XP 002480074.1) & Talaromyces stipitatus ATCC 10500 & $87 \%$ \\
\hline & glutamine synthetase, putative (XP 002143731.1) & Penicillium marneffei ATCC 18224 & $83 \%$ \\
\hline & glutamine synthetase (XP 747724.1) & Aspergillus fumigatus Af293 & $82 \%$ \\
\hline \multirow[t]{3}{*}{$g \ln B$} & glutamine synthetase (XP 002147563.1) & Penicillium marneffei ATCC 18224 & $87 \%$ \\
\hline & glutamine synthetase (XP 002481714.1) & Talaromyces stipitatus ATCC 10500 & $86 \%$ \\
\hline & glutamine synthetase (XP 001266733.1) & Neosartorya fischeri NRRL 181 & $86 \%$ \\
\hline \multirow[t]{3}{*}{ gdh1 } & NAD + dependent glutamate dehydrogenase, putative (XP 002144569.1) & Penicillium marneffei ATCC 18224 & $91 \%$ \\
\hline & NAD + dependent glutamate dehydrogenase, putative (XP 002144568.1) & Penicillium marneffei ATCC 18224 & $95 \%$ \\
\hline & NAD + dependent glutamate dehydrogenase, putative (XP 002340968.1) & Talaromyces stipitatus ATCC 10500 & $94 \%$ \\
\hline \multirow[t]{3}{*}{ gdh2 } & Glutamate/Leucine/Phenylalanine/Valine/dehydrogenase, putative (XP 002341081.1) & Talaromyces stipitatus ATCC 10500 & $80 \%$ \\
\hline & Glutamate/Leucine/Phenylalanine/Naline/dehydrogenase, putative (XP 002144464.1) & Penicillium marneffei ATCC 18224 & $78 \%$ \\
\hline & NAD- specific glutamate dehydrogenase, putative (XP 001821419.1) & Aspergillus oryzae RIB40 & $71 \%$ \\
\hline
\end{tabular}

\section{NMR analysis of violet pigment}

In the purification of the major violet pigment, Gln- $\mathrm{V}$, a yield of at least $0.3 \mathrm{~g}$ was obtained from a 2.5 -L culture following the first silica gel column chromatography step. The yield of the purified preparation for NMR analysis was $3.4 \mathrm{mg}$. Gln-V is a blue-black powder. The ${ }^{1} \mathrm{H}$ and ${ }^{13} \mathrm{C}$ NMR spectral data for Gln-V determined here and PP-V (Ogihara et al. 2000) are shown in Table 3. The results of NMR analyses indicate that the chemical shift value of $\mathrm{Gln}-\mathrm{V}$ is in accordance with that of PP-V. The coupling constant between H-10 and H-11 (13.0 Hz) indicated the presence of a $Z$ configuration. The stereochemistry of the double bond at C-10 was further elucidated by differential nuclear Overhauser effects (NOE). The relationship among $\mathrm{H}-5, \mathrm{H}-10$, and $\mathrm{H}-11$ also confirmed the $Z$ configuration. Violet pigment $\mathrm{Gln}-\mathrm{V}$ was thus identified as PP-V [(10Z)-12-carboxyl-monascorubramine].

\section{Effect of GS inhibition on pigment production}

The effect of GS inhibition on pigment production is shown in Figure 4. The amount of PP-V was markedly decreased with increasing GS-inhibitor, MSX, concentration.

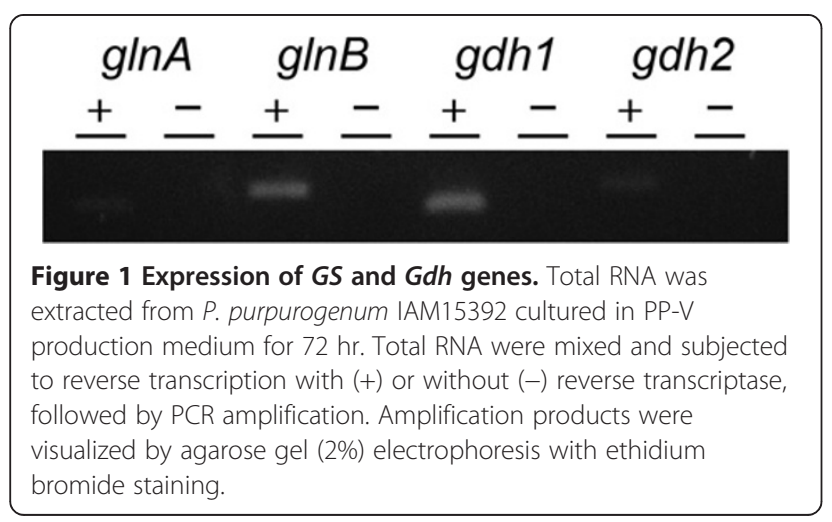

In contrast, $\mathrm{PP}-\mathrm{O}$ production was little affected by MSX (Figure 4), and no inhibition of growth of $P$. purpurogenum IAM15392 or PP-O production was observed up to $2 \mathrm{mM}$ MSX.

\section{Discussion}

P. purpurogenum IAM15392 has been found to produce amino derivatives of Monascus pigment homolog, PP-V,

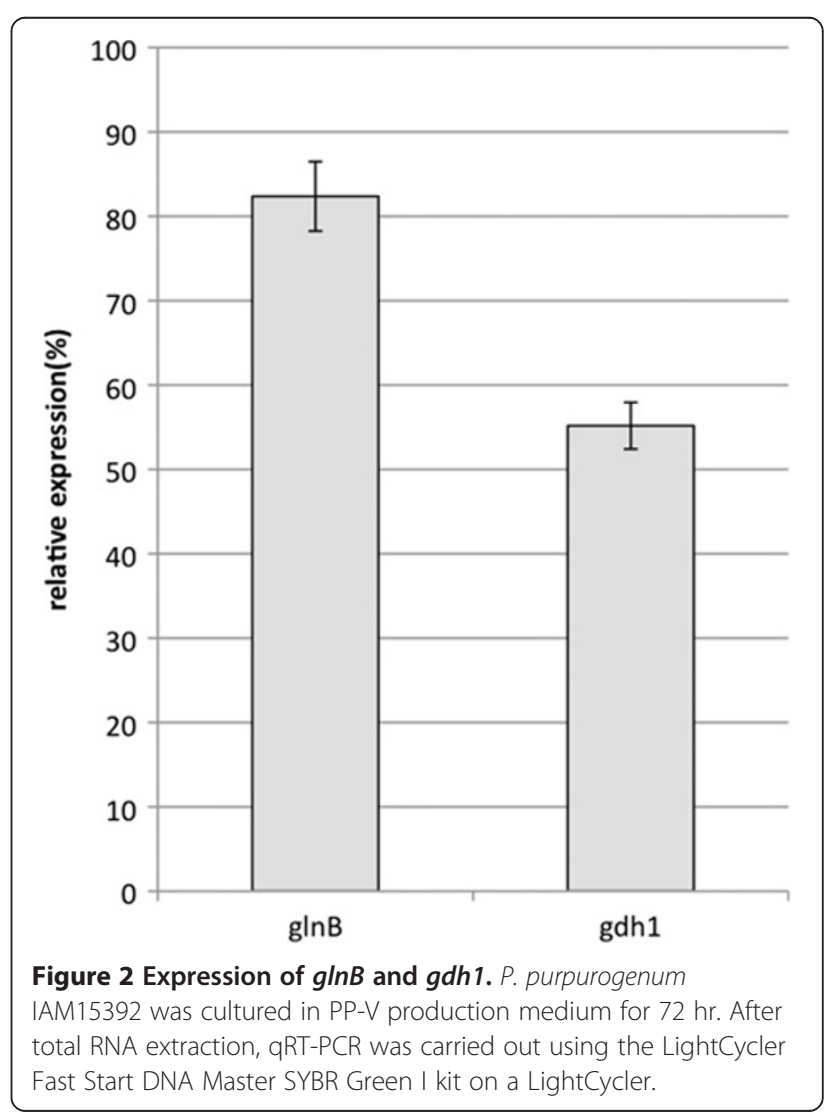




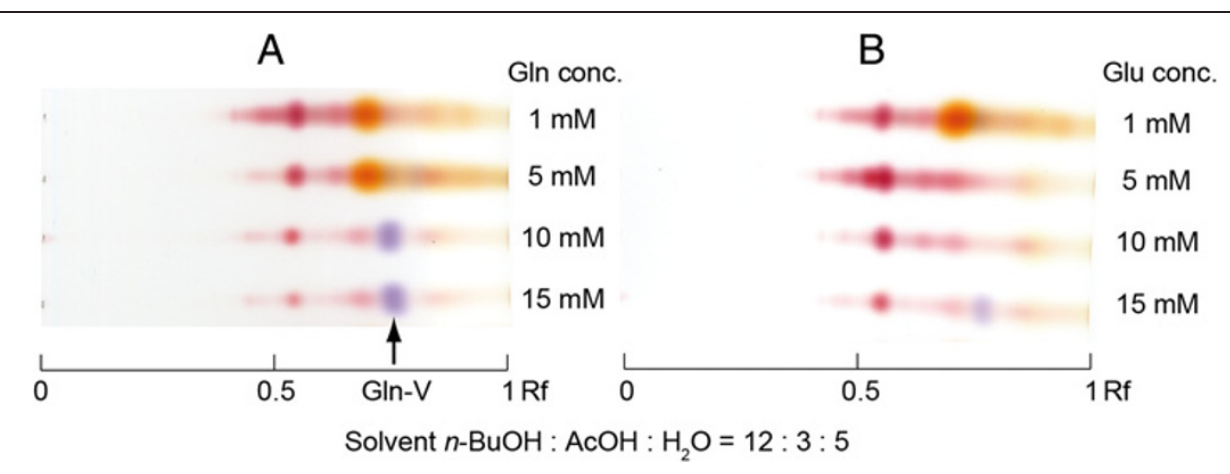

Figure 3 Silica gel TLC profiles of culture filtrate pigments and the effect of Gln and Glu on pigment production. (A) PP-V production medium containing 1 to $15 \mathrm{mM} \mathrm{L-glutamine.} \mathrm{(B)} \mathrm{PP-V} \mathrm{production} \mathrm{medium} \mathrm{containing} 1$ to $15 \mathrm{mM} \mathrm{L-glutamate.} \mathrm{Pigments} \mathrm{were} \mathrm{extracted} \mathrm{from}$ cultures incubated for $120 \mathrm{hr}$ with EtOAc and separated on silica gel TLC using developing solvents $n-\mathrm{BuOH}: \mathrm{AcOH}: \mathrm{H}_{2} \mathrm{O}$ (12:3:5). The violet pigment at Rf 0.75 was identified as PP-V. Smaller compound than Gln-V ( $R f=0.75)$ was observed. In our other researches, Smaller compound was considered Amino acid derivatives of Monascus pigment homologs (date not shown).

Table $3{ }^{13} \mathrm{C}$ and ${ }^{1} \mathrm{H}$ NMR spectral date of GIn-V and PP-V

\begin{tabular}{|c|c|c|c|c|}
\hline \multirow[b]{2}{*}{ Pos. No. } & \multicolumn{2}{|l|}{ Gln-V } & \multicolumn{2}{|l|}{ PP-V } \\
\hline & $\delta_{c}$ & $\delta_{\mathrm{H}}$ & $\delta_{c}$ & $\delta_{\mathrm{H}}$ \\
\hline 2 & 171.7 & & 171.2 & \\
\hline 3 & 97.8 & & 97.5 & \\
\hline $3 a$ & 169.0 & & 168.6 & \\
\hline 4 & 96.1 & $6.45(1 \mathrm{H}, \mathrm{s})$ & 95.7 & $6.49(1 \mathrm{H}, \mathrm{s})$ \\
\hline $4 a$ & 152.9 & & 152.5 & \\
\hline 5 & 123.0 & $7.12(1 \mathrm{H}, \mathrm{s})$ & 122.5 & $7.16(1 \mathrm{H}, \mathrm{s})$ \\
\hline 6 & 152.0 & & 151.4 & \\
\hline 8 & 143.9 & $8.34(1 \mathrm{H}, \mathrm{s})$ & 143.3 & $8.37(1 \mathrm{H}, \mathrm{s})$ \\
\hline $8 a$ & 118.5 & & 117.9 & \\
\hline 9 & 197.9 & & 197.4 & \\
\hline $9 a$ & 85.0 & & 84.6 & \\
\hline $9 \mathrm{a}-\mathrm{CH} 3$ & 30.9 & $1.46(3 \mathrm{H}, \mathrm{s})$ & 30.4 & $1.50(3 \mathrm{H}, \mathrm{s})$ \\
\hline 10 & 135.4 & $6.76(1 \mathrm{H}, \mathrm{d}, J=13.0)$ & 134.7 & $6.78(1 \mathrm{H}, \mathrm{d}, J=13.2)$ \\
\hline 11 & 131.2 & $6.76(1 \mathrm{H}, \mathrm{d}, J=13.0)$ & 130.9 & $6.09(1 \mathrm{H}, \mathrm{d}, J=13.2)$ \\
\hline 12 & 167.1 & & 166.8 & \\
\hline 13 & 193.9 & & 193.5 & \\
\hline 14 & 39.7 & $2.63(2 \mathrm{H}, \mathrm{t}, J=7.3)$ & 39.2 & $2.65(2 \mathrm{H}, \mathrm{t}, J=7.3)$ \\
\hline 15 & 25.2 & $1.44(2 \mathrm{H}$, quintet,$J=7.3)$ & 24.7 & $1.46(2 \mathrm{H}$, quintet, $J=7.3)$ \\
\hline 16 & 29.6 & $1.20-1.23(8 \mathrm{H}, \mathrm{m})$ & 29.1 & $1.23-1.25(8 \mathrm{H}, \mathrm{m})$ \\
\hline 17 & 29.2 & $1.20-1.23(8 \mathrm{H}, \mathrm{m})$ & 28.7 & $1.23-1.25(8 \mathrm{H}, \mathrm{m})$ \\
\hline 18 & 30.8 & $1.20-1.23(8 \mathrm{H}, \mathrm{m})$ & 31.8 & $1.23-1.25(8 \mathrm{H}, \mathrm{m})$ \\
\hline 19 & 22.6 & $1.20-1.23(8 \mathrm{H}, \mathrm{m})$ & 22.1 & $1.23-1.25(8 \mathrm{H}, \mathrm{m})$ \\
\hline 20 & 14.5 & $0.82(8 \mathrm{H}, \mathrm{t}, J=7.0)$ & 14.0 & $0.84(8 \mathrm{H}, \mathrm{t}, J=7.0)$ \\
\hline
\end{tabular}

Measured in DMSO- $d_{6}$.

$125 \mathrm{MHz}$ for ${ }^{13} \mathrm{C}$ and $500 \mathrm{MHz}$ for ${ }^{1} \mathrm{H}$. 


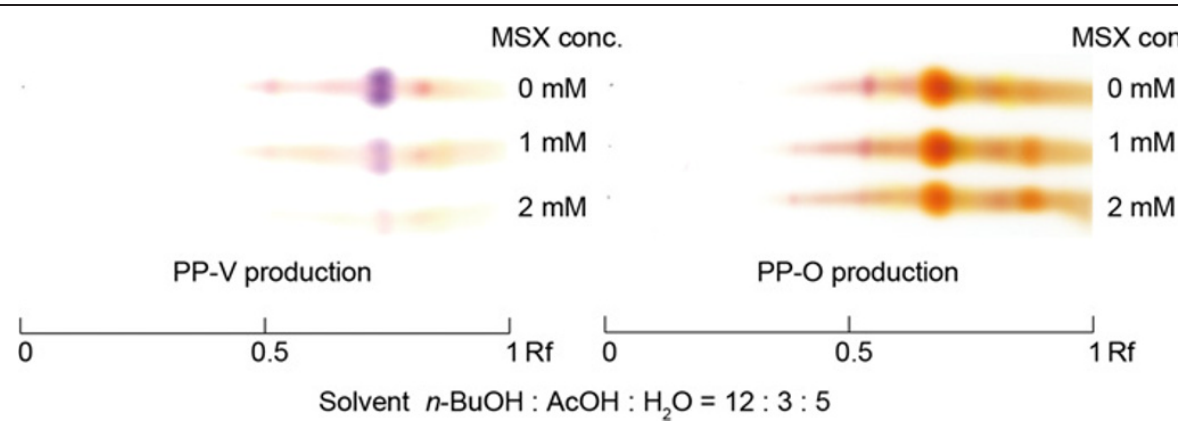

Figure 4 Silica gel TLC profiles of culture filtrate pigments and the effect of GS inhibitor on pigment production. PP-V or PP-O production medium cultures containing 0, 1 and 2 mM MSX were cultured for $72 \mathrm{hr}$. Pigments were extracted with EtOAc and resolved on silica gel TLC using developing solvent $n-\mathrm{BuOH}: \mathrm{AcOH}: \mathrm{H}_{2} \mathrm{O}$ (12:3:5). Violet pigment at $\mathrm{Rf} 0.75$ was identified as PP-V. Orange pigment at Rf 0.65 was identified as PP-O.

in culture with a medium containing ammonium nitrate (Ogihara et al. 2000). Here, we investigated whether ammonium that is transported into the cell acts directly or is incorporated into amino acids prior to $\mathrm{PP}-\mathrm{V}$ production.

Ammonia taken into the cell is converted to Glu and Gln through an ammonia assimilation process catalyzed in fungi by Gdh to form Glu, or by GS to form Gln (Hammond and Wood 1985; Casper et al. 1985; DunnColeman et al. 1981; Limon-Lason et al. 1977). Therefore, we examined the genes coding for GS and Gdh in $P$. purpurogenum IAM15392, and their expression. Genes from other filamentous fungi were used to produce specific primers for amplification and showed significant homology to $g \ln A$ and $g \ln B$ of GS and $g d h 1$ and $g d h 2$ of Gdh in P. purpurogenum IAM15392 (Table 2). RT-PCR demonstrated that $g \ln B$ and $g d h 1$ are expressed in culture conditions conducive to PP-V production. Further, $g \ln B$ and $g d h 1$ expression levels show no marked differences in expression, suggesting that both are involved in ammonia assimilation.

The violet pigment produced by $P$. purpurogenum IAM15392 was identified as PP-V, and the addition of Gln and Glu as nitrogen sources stimulated its production, though Gln had a much greater effect than Glu. Therefore, we conclude that the ammonia assimilation by GS is important in PP-V production. Gln is converted to Glu and ammonia by glutaminase. Glutaminases have been identified in bacteria, yeast, fungi, and mammals, and they play an important role in nitrogen metabolism (Durá et al. 2002; Heini et al. 1987; Imada et al. 1973). We consider that the ammonia generated by glutaminase in these cultures is used in PP-V production. Amino acid derivatives of Monascus pigments are known to be produced as watersoluble pigment by Monascus spp. when amino acids are added to the culture medium (Lin et al. 1992; Blanc et al. 1994; Hajjaj et al. 1997; Sato et al. 1997; Jung et al. 2003). In this study, $P$. purpurogenum IAM15392 produced an amino derivative pigment, PP-V, and as an EtOAc-soluble pigment when Gln or Glu are added to the culture medium. Hence, we consider that $P$. purpurogenum IAM15392 and Monascus spp. utilize a different nitrogen source for pigment production.

MSX is known to inhibit GS of fungi, yeasts and plants, and it is used to examine the influence of GS on secondary metabolite biosynthesis on GS in the filamentous fungus (Muñoz and Agosin 1993). Here, PP-V production was reduced, but not completely inhibited, by MSX. For the addition of Glu, a small quantity of PP-V was produced. Therefore, it is thought that Glu formed from ammonia by Gdh is also used in PP-V production. However, the decrease in PP-V production by MSX is remarkable. Hence, we demonstrate here that the glutamine synthesis of ammonium by GS is a critical reaction in the PP-V production pathway.

We conclude that ammonia is utilized as a nitrogen source in the production of PP-V after first being incorporated into amino acids. The nitrogen atom in the nitro-compound contributes to the expression of various biological activities in medical and agrochemical compounds. The next area of research will be to identify the enzymes that actually introduce nitrogen into the pyranoid ring of $\mathrm{PP}-\mathrm{O}$.

\section{Competing interests}

The authors declare that they have no competing interests.

\section{Acknowledgements}

We thank the General Reserch Institute of the College of Bioresource Sciences of Nihon University for the use of the ECA-500 NMR spectrometer, the JMS-SX-102A MS spectrometer, and the Center for Natural Environment Sciences at Nihon University for the use of LightCycler 330.

Received: 23 January 2013 Accepted: 20 March 2013

Published: 28 March 2013

\section{References}

Akihisa T, Tokuda H, Ukiya M, Kiyota A, Yasukawa K, Sakamoto N, Kimura Y, Suzuki T, Takayasu J, Nishino H (2005a) Anti-tumor-initiating effects of monascin, an azaphilonoid pigment fromthe extract of Monascus pilosus fermented rice (Red-mold rice). Chem Biodivers 2:1305-1309

Akihisa T, Tokuda H, Yasukawa K, Ukiya M, Kiyota A, Sakamoto N, Suzuki T, Tanabe N, Nishino H (2005b) Azaphilones, furanoisophthalides, and amino 
acids from the extracts of Monascus pilosus-fermented rice (Red-mold rice) and their chemopreventive effects. J Agric Food Chem 53:562-565

Arai T, Umemura S, Ota T, Ogihara J, Kato J, Kasumi T (2012) Effects of inorganic nitrogen sources on the production of PP-V [(10Z)-12-carboxylmonascorubramine] and the expression of the nitrate assimilation gene cluster by Penicillium sp. AZ. Biosci Biotechnol Biochem 76(1):120-124

Birch AJ, Cassera A, Fitton P, Holker JS, Smith H, Tomsor GA, Walley WB (1962) Studies in relation to biosynthesis. Part XXX. Rotation, monascin and rubropuntatin. J Chem Soc:3583-3592, 10.1039/JR9620003583

Blane PJ, Loret MO, Goma G (1995) Production of citrinin by various species of Monascus. Biotechnol Lett 17:291-294

Blanc PJ, Loret MO, Santerre AL, Pareilleux A, Prome D, Prome JC, Laussac JC, Goma G (1994) Pigments of Monascus. J Food Sci 59:862-865

Bu'Lock JD, Smith JR (1968) Modified anthraquinones from Penicillium islandicum. J Chem Soc(C):1941-1943, 1943

Cason J, Correia JS, Hutchison RB, Porter RF (1962) The structure of trimethylherqueinone B. Tetrahedron 18:839-851

Casper P, Bode R, Birnbaum D (1985) Untersuchungen zur Regulation der Ammonium assimilation von Candida maltosa. J Basic Microbiol 25:95-101

Chen FC, Manchand PS, Whelly WB (1971) The chemistry of fungi. Pare XXIV. The structure of monascin. J Chem Soc:3577-3586, 10.1039/J39710003577

Chen MH, Johns MR (1993) Effect of pH and nitrogen source on pigment production by Monascus purpureus. Appl Microbiol Biotechnol 40:132-138

Dufosse $L$ (2006) Microbial production of food grade pigments. Food Technol Biotechol 44:313-321

Dunn-Coleman NS, Robey EA, Tomsett AB, Garrett RH (1981) Glutamate synthase levels in Neurospora crassa mutants altered with respect to nitrogen metabolism. Mol Cell Biol 1:158-164

Durá AM, Flores M, Toldrá F (2002) Purification and characterization of a glutaminase from Debaryomyces spp. Int J Food Microbiol 76:117-126

Fielding BC, Holker JSE, Jones DE, Powell ADG, Richmond KW, Robertson A, Whelly WB (1961) The chemistry of fungi. Part XXXIX. The structure of monascin. J Chem Soc:4579-4583, 10.1039/JR9610004579

Fowell ADG, Robertson A, Whelly WB (1956) Monascorubramine. J Chem Soc Spec Publ 5:27-34

Fuska J, Proska B, Uhrin D (1988) The antibiotic PSX-1 produced by Penicillium stipitatum is identical with Botryodiplodin. Folia Microbiol (Progue) $33: 238-240$

Gatenbeck S (1959) Studies of mono-C-methylquinalizarins in relation to a phenolic metabokite of Penicillium islandicum. Acta Chem Scand 13:705-710

Hadfield JR, Holker JSE, Stanway DN (1967) The biosynthesis of fungal metabolites. Part II. The $\beta$-oxo-lactone equipments in rubropunctatin and monascorubrin. J Chem Soc 19:751-755

Hajjaj H, Klaebe A, Loret MO, Tzedakis T, Goma G, Blanc PJ (1997) Production and identification of $\mathrm{N}$-glucosylmonascorubramine from Monascus ruber and occurrence of electron donor-acceptor complexes in these pigments. Appl Environ Microbiol 63:2671-2678

Haws EJ, Holker JSE (1961) The chemistry of fungi. Part XXXVIII. J Chem Soc:38203829, 10.1039/JR9610003820

Hammond JBW, Wood DA (1985) Metabolism, biochemistry and physiology. Biology and Technology of the Ctlltivated Mashrooms, Chichester \& New York, pp 63-80

Heini HG, Gebhardt R, Brecht A, Mecke D (1987) Purification and characterization of rat liver glutaminase. Eur J Biochem 162:541-546

Hiroi T, Shima T, Isobe A, Kimura S (1975) Studies on the structure of two pigment obtained from Monascus sp. J J.pn Soc Food Nutr 28(9):497-502

Imada A, Igarasi S, Nakahama K, Isono M (1973) Asparaginase and glutaminase activities of micro-organisms. J Gen Microbiol 76:85-99

Jung H, Kim C, Kim K, Shin CS (2003) Color characteristics of Monascus pigments derived by fermentation with various amino acids. J Agric Food Chem 51:1302-1306

Juzlova P, Martinkova L, Kren V (1996) Secondary metabolites of the fungus Monascus: a review. J Ind Microbiol 16:163-170

Kim C, Jung H, Kim YO, Shin CS (2006) Antimicrobial activities of amino acid derivatives of monascus pigments. FEMS Microbiol Lett 264(1):117-124

Kobayashi A, Yata S, Hino T, Kawazu K (1987) A new fungal naphthoquinone which stimulates the production of antifungal compounds in alfalfa callus. Agric Biol Chem 51:2857-2860

Kurono M, Nakanishi K, Shindo K, Tada M (1963) Biosynthesis of monascorubrin and monascoflavin. Chem Pharm Bull 11(3):359-362
Limon-Lason J, Lara M, Resendiz B, Mora J (1977) Regulation of glutamine synthetase in fed-batch cultures of Neurospora crassa. Biochem Biophys Res Commun 78:1234-1240

Lin TF, Yakushijin K, Büchi GH, Demain AL (1992) Formation of water-soluble Monascus red pigments by biological and semi-synthetic processes. J Ind Microbiol 9:173-179

Manchand PS, Whelly WB, Chen FC (1973) Isolation and structure of ankaflavin. Phytochemistry 12:2531-2538

Muñoz GA, Agosin E (1993) Glutamine involvement in nitrogen control of gibberellic acid production in Gibberella fujikuroi. Appl Environ Microbiol 59:4317-4322

Ogihara J, Kato J, Oishi K, Fujimoto Y, Eguchi T (2000) Production and structural analysis of PP-V, a homologue of monascorubramine, produced by anew isolate of Penicillium sp. J Biosci Bioeng 90:549-554

Ogihara J, Kato J, Oishi K, Fujimoto Y (2001) Biosynthesis of PP-V, a monascorubramine homologue, by Penicillium sp. AZ. J Biosci Bioeng 90 (6):678-680

Ogihara J, Oishi K (2002) Effect of Ammonium Nitrate on the Production of PP-V and Monascorubrin Homologues by Penicillium sp. AZ. J Biosci Bioeng 93:54-59

Peterson RE, Grove MD (1983) Isolation of xanthomegnin from Penicillium viridicatum by preparative high-pressure liquid chromatography. Appl Environ Microbiol 45:1937-1938

Sato K, Goda Y, Sakamoto S, Shibata H, Maitani T, Yamada T (1997) Identification of major pigments containing D-amino acid units in commercial Monascus pigments. Chem Pharm Bull 45:227-229

Simonart P, Verachtert H (1966) Coposes phenoliques produits par Aspergillus fumigatus Fresenius et par Penicillium spinulosum Thom. Bull Soc Chim Biol 48:943-950

Singh PD, Johnson JH, Aklonis CA, Bush K, Fisher SM, O'sullivan J (1985) Two new inhibitors of phospholipase $A_{2}$ produced by Penicillium chermesinum. Taxonomy, fermentation, isolation, structure determination and biological properties. J Antibiot 38:706-712

Takeda N, Seo S, Ogihara Y, Sankawa U, litaka I, Kitagawa I, Shibata S (1973) Studies on fungal metabolites-XXXIAnthraquinonoid coloring matters of Penicillium islandicum Sopp and some other fungi (-) luteoskyrin, (-) rubroskyrin, $(+)$ rugulosin and their related compounds. Tetrahedron 29:3703-3719

Wang Y, Ju X, Zhou Y (2005) The variability of citrinin production in Monascus type cultures. Food Microbiol 22:145-148

\section{doi:10.1186/2191-0855-3-19}

Cite this article as: Arai et al:: Importance of the ammonia assimilation by Penicillium purpurogenum in amino derivative Monascus pigment, PPV, production. AMB Express 2013 3:19.

\section{Submit your manuscript to a SpringerOpen ${ }^{\circ}$ journal and benefit from:}

- Convenient online submission

- Rigorous peer review

- Immediate publication on acceptance

- Open access: articles freely available online

- High visibility within the field

- Retaining the copyright to your article

Submit your next manuscript at $>$ springeropen.com 